Lournal of Sustainable Cement-Based Materials

Volume 7, 2018 - Issue

Articles

\title{
Binding gel characterization of alkali-activated binders based on palm oil fuel ash (POFA) and fly ash
}

Nurulhuda Nadziri,Idawati Ismail (iD) \&Sinin Hamdan

Pages 1-14 | Published online: 07 Mar 2017

- Download citation

https://doi.org/10.1080/21650373.2017.1299054

\section{Abstract}

Pastes of palm oil fuel ash (POFA) and fly ash geopolymer activated with sodium hydroxide $(\mathrm{NaOH})$ and combination of $\mathrm{NaOH}$ with sodium silicate $\left(\mathrm{Na}_{2} \mathrm{SiO}_{3}\right)$ were prepared and cured at $80^{\circ} \mathrm{C}$ for a duration of 7,28 , and 90 days. The hydrated binding gel products were studied on phase, morphology, and bonding characterization. From these analyses, calcium-sodium-silicate-hydrate (C/N$\mathrm{S}-\mathrm{H}$ ) gel type appear to form in sole POFA binder but at a very low $\mathrm{Ca} / \mathrm{Si}$ ratio, while sole fly ash geopolymer binder consists of sodium-alumina-silicatehydrate $(\mathrm{N}-\mathrm{A}-\mathrm{S}-\mathrm{H})$ binding gel product with a significant $\mathrm{Na} / \mathrm{Si}$ ratio, regardless of activator types. When both precursors were used, a combination of both gel types was formed, however, Fourier transform infrared spectroscopy and energydispersive $\mathrm{X}$-ray analyses show that the $\mathrm{N}-\mathrm{A}-\mathrm{S}-\mathrm{H}$ gel is a more dominant product in the binder compared to the $\mathrm{C} / \mathrm{N}-\mathrm{S}-\mathrm{H}$ gel.

\section{Keywords:}

\section{geopolymeralkali-activated binderpalm oil fuel ashfly ash}

